\title{
Easter Island: A Last Outpost
}

\section{Tom Harrisson}

Man is the only land vertebrate to have successfully colonised the remote Easter Island, and his domestic animals graze almost the whole island. Three, perhaps four species of sea turtle occur, and of fourteen species of seabird, eight breed, some in very large numbers. Five bird species have been introduced with unhappy results. There is now a weekly air service to Easter Island, and Dr. Harrisson, who spent eight days there early this year, urges the need for careful study of conservation problems and support for the Chilean government.

Easter Island (Rapanui), 11 miles long and between two and seven across, lies at $27^{\circ}$ south, about 2,100 miles west of continental South America, and 2,200 miles south-west of the Galapagos. Until the Chilean Airline LAN, recently started a weekly air service touching there between Tahiti and Santiago, Rapanui was only occasionally accessible by ocean-going vessels, although a few individual travellers, like the Duke of Edinburgh with Lord Mountbatten and friends early this year, called in. Thor Heyerdahl's longer expedition regrettably contained no biologist. Zoological literature at all levels is extremely meagre. This note calls attention to the present strange situation on Easter Island as a base line for consideration now that large-scale tourism development is planned. I was on Rapanui with my wife for eight days in February 1971. We were able to cover most of the island and to land on the difficult offshore islets.

The 'miracle' of Easter Island is that men not only got there, but developed a unique, elaborate, dynamic and highly creative culture of their own, with a few thousands population (now c. 1500), wholly isolated from the great trends of developing civilisation. No other land vertebrate is known to have reached Rapanui and survived. But fourteen species of seabird have now been identified, of which at least eight nest, sometimes in very large numbers (Johnson, 1970; Harrison). Moreover, probably at least three species of large marine turtle visit the island with some regularity - there has been no previous record of any (Pritchard; Bustard; and below).

This is one of only two possible breeding stations for all these birds and reptiles in an area covering over $2,000,000$ square miles of the south-east Pacific. The other is Salla y Gomez, an uninhabited reef about 800 miles to the north-east, on which there appears to be near zero scientific literature (King, 1971).

These oceanic arrivals, sharply seasonal and centred around the 'autumn' months, evidently made an enormous impression on the ultra-insular human residents. Migration events played a major part in their cosmic concepts, expressed also in lavish rock and wood carving; the annual rites of kingship by contest, decided by the first to obtain the egg of a sooty tern; and the still unsolved rongorongo script, largely of bird symbols. 
Rapanui has been a sanctuary by nature of its position alone, fortified by the conservationist approach of the pagan islanders, who minded - indeed, virtually worshipped - sections of the fauna, as though they were visitors from outer space. Now, with only Christian sanctions and the prospect of a dollar deluge (already beginning) this position is at risk.

The concentrated sea-bird population is especially vulnerable. The islanders are getting better supplied with outboards, fuel and other technical equipment, alongside a new demand for visits, souvenirs, etc. Apart from a few red-tailed tropic-birds Phaethon rubricauda the whole avifauna is centred on four little islets off the east coast, three close together near the main island's only settlement and harbour. While we were there, an expedition gathered all the eggs and birds that could be collected, including two sitting adults of the Kermadec petrel Pterodroma neglecta. From the wing of one adult, Dr King of the Smithsonian Institution was able to determine the race as neglecta also - its previous nearest known breeding station was the uninhabited Ducie Island, 1000 miles to the west (King, 1967; 1971).

The ornithological situation is unhelpfully complicated by the introduction, in 1928, of a scavenger-predator, the chimango caracara Milvago chimango from South America, which has reached a success peak here. The optimum had got to over 50 birds together in February and many were in smaller groups on the slopes leading to the great Orongo Cliff, overlooking the islets, centre of the bird cult and now well labelled as a national park. But the caracaras are all over the island, from peregrine-style cliffs to cultivated land and the airstrip, and the islanders say that they are devastating the sea-bird chicks. Also introduced are the Chilean Tinamou Nothoprocta perdicaria (1885), two South American passerines and the house sparrow Passer domesticus. The caracara appears to have controlled and probably reduced the populations of these, except the very abundant house sparrow, which escapes largely by nesting in stone walls and the man-made caves which are a striking feature in parts of the island. Both the hawk and the sparrow live to a considerable extent on insects associated with the droppings of imported cattle and large droves of horses, now feral and particularly numerous in the national park area. A list of all the birds is on page 116.

The hitherto neglected marine turtles round Easter Island may turn out to be of special importance. Some remarkably detailed petroglyphs, carapaces retained as heirlooms, and discussion with informants suggest that at least three species, possibly four, visit the beaches and sheltered bays, for food and/or nesting. Wonderfully well-made stone towers were erected along sections of the coastline and are still called turtle towers - though they have not been used in living memory. Again there are strong indications that in the past turtles were not indiscriminately slaughtered but respected, but those sanctions have not operated since the island went Catholic in the last century. Turtle visitors are now much more scarce and irregular.

Finally, the flora and invertebrate fauna of Rapanui, on which I am not competent to speak in any detail. Clearly this also has been highly disturbed in historic times. Most of the original flora must have 


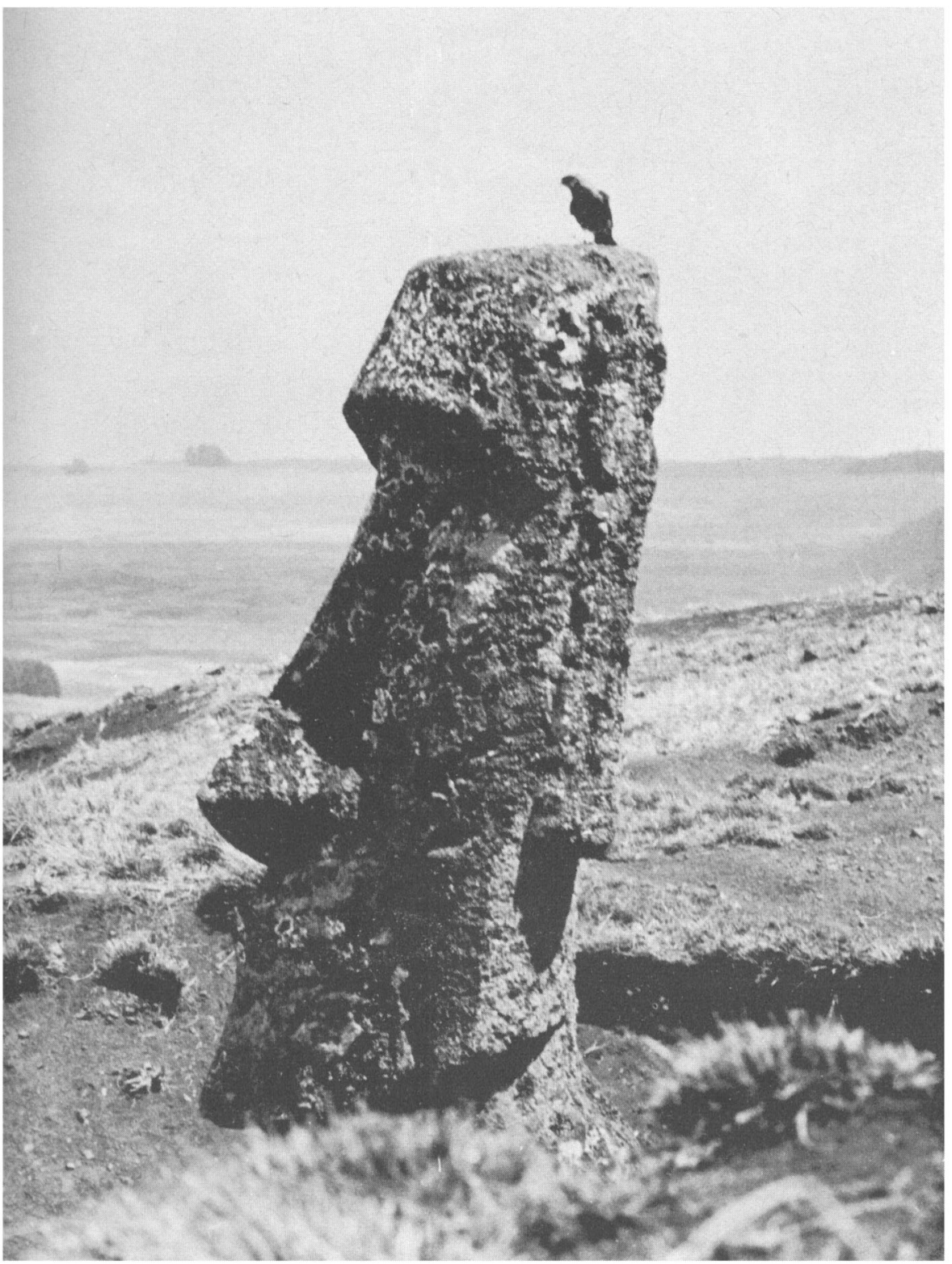

CARACARA ON EASTER ISLAND, perched on one of the stone heads in Raranaku Volcano. All the Easter Island photographs are by Christine Harrisson. 


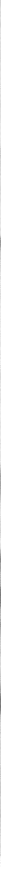

KERMADEC PETREL and its egg taken this year, as described by Tom Harrisson. BIRD ISLANDS off Easter Istand where a high proportion of the breeding seabirds are found, seen from the top of the great Orongo cliff, centre of the bird cult. The bird carvings on the cliffs can be seen.

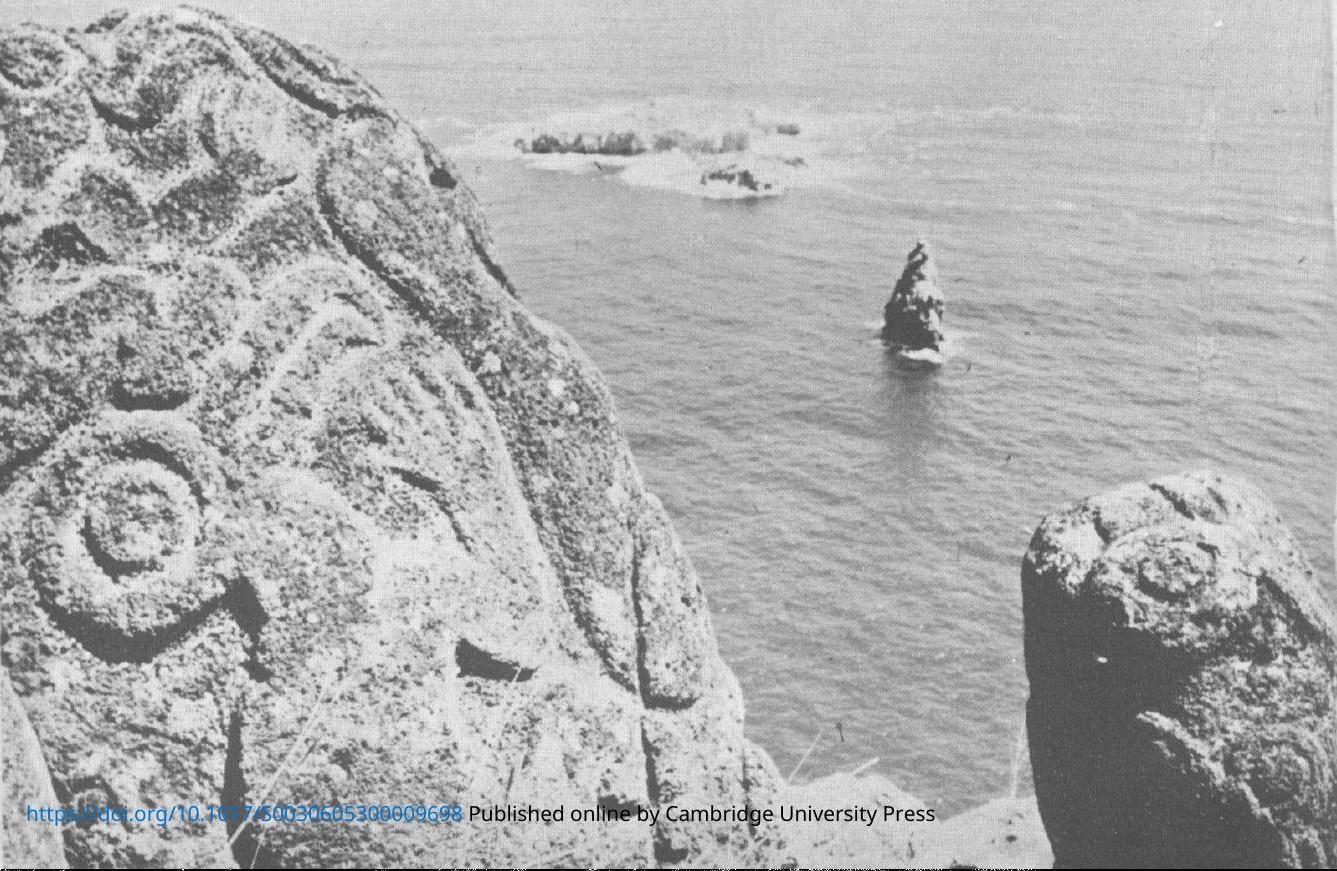




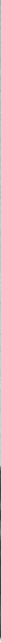

Typical coastal scene on Easter Island with old volcano in the background. The lone coconut-palm and the now feral horses are both introduced,

Despite many past disturbances and present limitations, here we have a uniquely remote tropical ecosystem,' which remains of the highest interest by virtue of its physical immunities as well as its unique cultural associations. I suggest the need for closer study, with vigorous support for the Chilean Government. As well as paying the necessary priority attention to conserving the archaeology and prehistory of the island (now actively in hand), attention should be turned to the almost equally immediate problems of the environment there as a whole, including the new hotels and other buildings at present being planned. In such a wonderful, beautiful, completely 'different' place - unspoiled indeed - it would be a tragedy if exploitation were to distort one acre. disappeared. The island has been forested erratically with groves of eucalyptus and other trees. Practically every inch of it not otherwise employed is grazed by the horses and cattle.

However, the Chilean Government is showing a freshly responsible and intelligent attitude to Easter Island. The problem of control is complex. The islanders, splendid people, have a highly independent attitude. They have been trampled upon from the outside too often in the past, and are now determined to have a say in their own destiny.

\section{REFERENCES}

BUSTARD, H. R., 1971 - personal comm. from A.N.U. Canberra. JOHNSON, A. W., MILLIER, W. R. and MOFFETT, G., 1970, Notes on the Birds of Easter Island. Ibis, 112: 532-538.

KING, WARREN, B., 1967, Sea birds of the Tropical Pacific Ocean, Washington (Smithsonian Institution).

KING, WARREN, B., 1971 - personal communications and identification of specimens.

HARRISSON, TOM, 1971, field notes and photographs; specimens at Cornell University.

PRITCHARD, PETER, 1971 - personal communication as Secretary of IUCN's Marine Turtle Group.

ZUCKERMAN, LORD, 1971 - personal communications. 


\section{Easter Island Birds}

English Name

Christmas Island Shearwater

Kermadec Petrel

Herald Petrel

Great Frigate-bird

Red-tailed Tropic-bird

White-tailed Tropic-bird

Sooty Tern

Brown Noddy

Grey Noddy

Grey-backed Tern

White Tern

White Booby

Giant Petrel

Cape Pigeon
Islanders'

Name

$\begin{array}{ll}\text { Kuma } & \begin{array}{l}\text { Puffinus nativitatis } \\ \text { Kakapa }\end{array} \\ \text { Kapaka } & \begin{array}{l}\text { Pterodroma neglecta } \\ \text { Pterodroma arminjoniana } \\ \text { heraldica }\end{array} \\ \text { Maoche } & \begin{array}{l}\text { Fregata minor } \\ \text { Phaethon rubricauda }\end{array} \\ \text { Tavake } & \begin{array}{l}\text { P. lepturus } \\ -\end{array} \\ \text { Manutara } & \text { Sterna fuscata } \\ \text { Tuao } & \text { Anous stolidus } \\ \text { Tavi } & \text { Procelsterna cerulea } \\ \text { Manutara } & \text { Sterna lunata } \\ \text { Kiakia } & \text { Gygis alba } \\ \text { Kena } & \text { Sula dactylatra } \\ \text { Ruru } & \text { Macronectes gigantea } \\ - & \text { Daption capensis }\end{array}$

Scientific Name

\section{Introduced Birds and Date of Introduction}

Chilean Tinamou

Chimango Caracara

Red-breasted Blackbird

House Sparrow

Common Diuca-finch
Nothoprocta perdicaria

Milvago chimango

Leistes militaris now extinct

Passer domesticus

Diuca diuca
1885

1928

1885

1928

1928

\section{Fur Seals and King Penguins}

Fur seals and king penguins had continued to increase on Heard Island, in the Antarctic, a party of the Australian National Antarctic Research Expeditions found in 1969. They counted 2660 fur seals, compared with 440 for the same areas in 1963; the colonies of king penguins at Spit Bay had doubled since 1965, and increased five times since 1963: 97 adults and 103 eggs or chicks were counted, and another colony of 40 adults with 17 eggs or chicks was seen in Southwest Bay. It is thought that the king penguins have probably migrated from the large colonies on the Kerguelen Islands, $430 \mathrm{~km}$. to the north-west.

\section{Wholesale Murder}

A horrifying pesticide story from Israel is told in the ICBP President's Newsletter. In 1970 flocks of larks, especially wintering skylarks, were doing considerable damage to seedling crops in semi-arid areas of the Negev and south-central Israel. The larks had formerly been kept down by birds of prey, but these had been exterminated by the Plant Protection Department, thus allowing the larks to multiply. To control them the Department spread large areas with sorghum grain poisoned with endrin. Many larks died, but so also did many mammal and migrating bird predators which fed on the poisoned birds. The Department had insisted on using endrin, and not a poison that would have avoided the secondary poisoning, because they thought that "the convulsions of the poisoned birds would scare away other birds from the area it was desired to protect'. 